\title{
THE IMPACT OF BLACK SPOT FUNGICIDES ON INTEGRATED MITE CONTROL IN PIPFRUIT
}

\author{
P.W. SHAW ${ }^{1}$, S.J. BRADLEY ${ }^{2}$ and J.T.S. WALKER ${ }^{2}$ \\ The Horticultural and Food Research Institute of New Zealand Ltd., \\ ${ }^{I}$ Nelson Research Centre, P.O. Box 220, Motueka \\ ${ }^{2}$ Hawkes Bay Research Centre, Private Bag 1401, Havelock North
}

\begin{abstract}
The effects of six protectant fungicides on integrated mite control (IMC) in pipfruit were evaluated in two trials in Nelson (1997-98 season) and Hawkes Bay (1998-99 season). Four of the fungicides were tested in two formulations. In the Nelson trial, thiram and ziram applied between September and mid-November reduced populations of the predatory mite, Typhlodromus pyri, and this allowed European red mite (Panonychus ulmi) numbers to increase. Metiram caused little disruption to predatory mites in this trial while captan and dithianon were not disruptive. An analysis of these effects showed that the fungicide active ingredients, rather than product formulations, were responsible for disruption. Mid-summer applications of ziram in the Hawkes Bay trial also reduced numbers of T. pyri, whereas tolylfluanid was not disruptive to integrated mite control.
\end{abstract}

Keywords: fungicides, formulation, Typhlodromus pyri, pipfruit, integrated mite control.

\section{INTRODUCTION}

Integrated mite control (IMC) using the organophosphate - resistant predatory mite, Typhlodromus pyri, for control of European red mite, Panonychus ulmi, (ERM) is a widely adopted strategy in New Zealand apple orchards. Successful IMC requires the use of selective pesticides that do not disrupt control by predatory mites (Wearing and Ashley 1982). Protectant fungicides considered compatible with IMC in New Zealand include captan, dithianon and thiram (Walker et al. 1989; Wearing and Wilton 1984), while the compatibility of another fungicide, ziram, has not been reported. However, thiram is listed as moderately toxic ( $50-75 \%$ mortality) to active stages of T. pyri by a European biocontrol company, Biobest biological systems (Biobest 1998) and it is reported to be slightly harmful (25-50\% mortality) to the predatory mite in field trials (Hassan et al. 1987).

The disruptive effects of two fungicides, mancozeb and metiram to IMC have been well documented from field trials (Wearing and Ashley 1982; Wearing and Proffit 1982; Wearing and Wilton 1984). Walker, Shaw and Cassidy (unpubl. data) found that both products suppressed T. pyri and disrupted mite control, with each additional application causing greater disruption and delaying the recovery of predator numbers.

There have been recent changes to fungicide formulations with a trend away from wettable powder (WP) to water dispersible granule (WG) formulations. The possible effects of these formulation changes on IMC have not been investigated. This paper reports the results from two field trials, which investigated the effects of early and midsummer use of protectant fungicides on IMC and the effects of different formulations.

\section{Trial 1}

\section{METHODS}

The trial was carried out on cv. 'Fuji' apples at the HortResearch Nelson Research Centre during the 1997-98 season. The treatments, formulation and product rates per 
hundred litres were captan (80WP and 80WG) 125g, thiram (80WP and 80WG) $150 \mathrm{~g}$, ziram (90WP and 76WG) $125 \mathrm{~g}$ and $150 \mathrm{~g}$, dithianon (500SC and $70 \mathrm{WG}$ ) $25 \mathrm{ml}$ and $18 \mathrm{~g}$, metiram (70DF) $125 \mathrm{~g}$. There were four single tree replicates of each treatment arranged in a randomised complete block design. On six occasions $(1,7,16,24$ October, 4 and 14 November), treatments were applied by hand-lance at a rate of approximately 4 litres/tree (2500 litres/ha). Twenty five leaves were randomly collected from each treatment replicate on 24 November, 6 January and 11 February. Leaves were brushed on to a plate with a mite brushing machine and the numbers of T. pyri and ERM were counted with the aid of a microscope.

\section{Trial 2}

This trial was carried out on cv. 'Royal Gala' apples at the HortResearch Hawkes Bay Research Centre during the 1998-99 fruit season. Treatments were ziram 76WG (150g/100litres), tolylfluanid 50WG (200g/100litres) and an untreated control. Each treatment had four single tree replicates arranged in a randomised complete block design. Six applications each of ziram and tolylfluanid were applied by hand-lance at a rate of approximately 5 litres/tree (3000 litres/ha) on 23 December 1998, 6, 26 January, 2, 13 and 23 February 1999. The current label claim for ziram is for $150 \mathrm{mls}$ per $100 \mathrm{~L}$ sprayed to point of runoff and for up to three sprays to be applied from third cover (early December) at 10-14 day intervals. However, actual use of ziram often exceeds this level, so the effect of both fungicides on mite predator populations was assessed after three and six applications. On 21 December (pre-treatment), 27 January and 2 March, 25 leaves per treatment replicate were collected and mites counted as described above in Trial 1.

\section{Data analysis}

Although raw means are presented in Tables 1-3, ANOVA and Fisher's LSD test were conducted on log transformed data for the numbers per leaf of ERM eggs and active stages of mites in both trials. In Trial 1, the same statistical analysis was completed on products with both WP and WG formulations to determine any effects from formulation on mite control.

\section{Trial 1}

\section{RESULTS}

By the first sampling date (ten days after the last treatments were applied), trees sprayed with the WG and WP formulations of thiram and ziram had significantly higher numbers of ERM and lower numbers of T. pyri $(\mathrm{P}<0.01)$ than those treated with the captan or dithianon treatments (Table 1).

TABLE 1: The mean number of ERM active stages and $T$. pyri active stages per leaf at each sampling date for the different fungicide formulations in Trial 1.

\begin{tabular}{|c|c|c|c|c|c|c|c|}
\hline \multirow{2}{*}{$\begin{array}{l}\text { Active } \\
\text { ingredient }\end{array}$} & \multirow{2}{*}{$\begin{array}{l}\text { Formu- } \\
\text { lation }\end{array}$} & \multicolumn{2}{|c|}{ 24-Nov-97 } & \multicolumn{2}{|c|}{ 6-Jan-98 } & \multicolumn{2}{|c|}{ 11-Feb-98 } \\
\hline & & ERM & T. pyri & ERM & T. pyri & ERM & T. pyri \\
\hline \multirow[t]{2}{*}{ captan } & WG & $0.19 a b^{1}$ & $0.59 \mathrm{~b}$ & $0.04 \mathrm{a}$ & $1.24 \mathrm{c}$ & $0.05 \mathrm{ab}$ & $0.54 \mathrm{a}$ \\
\hline & WP & $0.01 \mathrm{a}$ & $0.80 \mathrm{~b}$ & $0.13 \mathrm{a}$ & $0.92 \mathrm{~cd}$ & $0.07 \mathrm{ab}$ & $0.53 \mathrm{a}$ \\
\hline \multirow[t]{2}{*}{ thiram } & WG & $0.80 \mathrm{bc}$ & $0.06 \mathrm{a}$ & $7.84 \mathrm{c}$ & $0.38 \mathrm{ab}$ & $0.85 \mathrm{bc}$ & $1.07 \mathrm{ab}$ \\
\hline & WP & $0.76 \mathrm{bc}$ & $0.03 \mathrm{a}$ & $3.02 \mathrm{bc}$ & $0.17 \mathrm{a}$ & $1.51 \mathrm{c}$ & $1.42 \mathrm{bc}$ \\
\hline \multirow[t]{2}{*}{ ziram } & WG & $0.77 \mathrm{c}$ & $0.05 \mathrm{a}$ & $6.87 \mathrm{c}$ & $0.42 \mathrm{abc}$ & $3.39 \mathrm{~d}$ & $1.70 \mathrm{bc}$ \\
\hline & WP & $0.85 \mathrm{c}$ & $0.05 \mathrm{a}$ & $6.70 \mathrm{c}$ & $0.39 \mathrm{ab}$ & $6.23 \mathrm{~d}$ & $2.08 \mathrm{c}$ \\
\hline \multirow[t]{2}{*}{ dithianon } & WG & $0.13 \mathrm{a}$ & $0.57 \mathrm{~b}$ & $0.08 \mathrm{a}$ & $1.28 \mathrm{c}$ & $0.00 \mathrm{a}$ & $0.40 \mathrm{a}$ \\
\hline & $\mathrm{SC}$ & $0.01 \mathrm{a}$ & $0.61 \mathrm{~b}$ & $0.07 \mathrm{a}$ & $0.97 \mathrm{c}$ & $0.00 \mathrm{a}$ & $0.39 \mathrm{a}$ \\
\hline metiram & DF & $0.53 \mathrm{abc}$ & $0.01 \mathrm{a}$ & $0.85 \mathrm{ab}$ & $0.74 \mathrm{bcd}$ & $0.12 \mathrm{ab}$ & $0.55 \mathrm{a}$ \\
\hline
\end{tabular}

${ }^{1}$ Figures in the same column not followed by the same letter are significantly different 
Similar results were recorded until the final sampling date on 11 February, by which time predator numbers had recovered in the thiram and ziram treatments in response to the cessation of spraying and the comparatively higher mite populations that developed. Predator numbers were initially very low (0.01/leaf) in the metiram treatment, but by 6 January, were similar to numbers in captan and dithianon treatments; ERM numbers remained low in the metiram treatment throughout the season. A comparison between captan, thiram and ziram showed that it was the active ingredient, rather than the granule or powder formulations of these fungicides, that affected predator mite numbers (Table 2). The interaction between formulation and active ingredient was not significant $(\mathrm{P}>0.05)$.

TABLE 2: The effect of active ingredient, formulation and the interaction of these factors on themean number of ERMactivestages and $T$. pyri activestages per leaf recorded for captan, thiram and ziram treatments (Trial1).

\begin{tabular}{llcccccc}
\hline \multirow{2}{*}{ Factor } & & \multicolumn{2}{c}{ 24-Nov-97 } & \multicolumn{2}{c}{ 6-Jan-98 } & \multicolumn{2}{c}{ 11-Feb-98 } \\
Active ingredient & & ERM & T. pyri & ERM & T. pyri & ERM & T. pyri \\
& thiram & $0.10 \mathrm{a}^{1}$ & $0.70 \mathrm{~b}$ & $0.09 \mathrm{a}$ & $1.08 \mathrm{~b}$ & $0.06 \mathrm{a}$ & $0.53 \mathrm{a}$ \\
& ziram & $0.81 \mathrm{~b}$ & $0.04 \mathrm{a}$ & $5.43 \mathrm{~b}$ & $0.28 \mathrm{a}$ & $1.18 \mathrm{~b}$ & $1.25 \mathrm{~b}$ \\
Formulation & & & $6.79 \mathrm{~b}$ & $0.41 \mathrm{a}$ & $4.81 \mathrm{c}$ & $1.89 \mathrm{c}$ \\
& granule & $0.57 \mathrm{a}$ & $0.29 \mathrm{a}$ & $3.28 \mathrm{a}$ & $0.49 \mathrm{a}$ & $2.60 \mathrm{a}$ & $1.34 \mathrm{a}$ \\
powder & $0.59 \mathrm{a}$ & $0.23 \mathrm{a}$ & $4.91 \mathrm{a}$ & $0.68 \mathrm{a}$ & $1.43 \mathrm{a}$ & $1.10 \mathrm{a}$ \\
Interaction & & n.s. & n.s. & n.s. & n.s. & n.s. & n.s. \\
\hline
\end{tabular}

${ }^{1}$ For each factor, figures in the same column not followed by the same letter are significantly different $(\mathrm{P}<0.05)$.

\section{Trial 2}

The numbers of ERM and T. pyri active stages were similar in all treatments at the pre-treatment count on 21 December. However by the 27 January (one day after the third application), numbers of ERM were significantly higher $(\mathrm{P}<0.05)$ in the ziram treatment compared to the tolylfluanid treatment and untreated control (Table 3). Mite numbers continued to increase and predator numbers declined in the ziram treatment. At the final sampling date on 2 March (seven days after the sixth spray application), the mean numbers of ERM and T. pyri per leaf in the ziram treatment were 9.68 and 0.11 respectively. There were significantly lower numbers of ERM, and higher counts of $T$. pyri, in both the tolylfluanid treatment and untreated control trees (Table 3).

TABLE 3: The mean number of ERMactivestages and $T$. pyri active stages per leaf at each sampling date for the different fungicide treatments in Trial 2.

\begin{tabular}{lcccccc}
\hline & \multicolumn{2}{c}{ 21-Dec-98 } & \multicolumn{2}{c}{ 27-Jan-99 } & \multicolumn{2}{c}{ 2-Mar-99 } \\
& ERM & T. pyri & ERM & T. pyri & ERM & T. pyri \\
\hline untreated & $0.56 \mathrm{a}^{1}$ & $0.76 \mathrm{a}$ & $0.59 \mathrm{a}$ & $1.03 \mathrm{~b}$ & $1.61 \mathrm{a}$ & $1.30 \mathrm{~b}$ \\
ziram & $0.39 \mathrm{a}$ & $0.52 \mathrm{a}$ & $1.81 \mathrm{~b}$ & $0.48 \mathrm{a}$ & $9.68 \mathrm{~b}$ & $0.11 \mathrm{a}$ \\
tolylfluanid & $0.58 \mathrm{a}$ & $0.78 \mathrm{a}$ & $0.52 \mathrm{a}$ & $0.45 \mathrm{a}$ & $1.96 \mathrm{a}$ & $0.96 \mathrm{~b}$ \\
\hline
\end{tabular}

${ }^{1}$ Figures in the same column not followed by the same letter are significantly different $(\mathrm{P}<0.05)$.

\section{DISCUSSION}

The two trials indicated that ziram and thiram treatments suppressed T. pyri populations and that this allowed ERM populations to increase. Suppression of predator numbers was evident after three to four applications and pipfruit growers 
typically may apply at least this number of either product. The disruption to predatory mites caused by thiram differs from earlier assessments of the fungicide. At that time, the use pattern of an occasional spray of thiram was considered compatible with IMC (Wearing and Ashley 1982; Wearing and Wilton 1984). However, results from this trial support the rating of thiram as between "slightly harmful" (25-50\% mortality) to T. pyri (Hassan et al. 1987) to "moderately toxic" (50-75\% mortality) (Biobest 1998). The trial results are also supported by the observations of some growers who have used thiram.

Ziram reduced $T$. pyri populations in Trial 1 over early summer, although it is generally not used at this time. However, results from the second trial indicated that this reduction also occurred during its recommended use period in mid-summer. Metiram was also disruptive to predator mites as reported by earlier studies (Collyer 1980; Wearing and Ashley 1982; Wearing and Wilton 1984; Walker et al 1989). However, T. pyri numbers recovered after spraying ceased and metiram showed little or no disruption to IMC in this trial.

The recovery of predator mite populations after applications of ziram, thiram and metiram ceased was partially in response to higher numbers of ERM that had developed in these treatments. These results suggest that the probability of poor biological mite control, and consequent miticide use, increases with each application of these products. Ziram and thiram appeared to be similarly disruptive to predator populations while metiram was only mildly disruptive. However, the possibility that a grower will require a late season miticide is increased, if multiple applications of any one of these fungicides are used, either on their own or in combination programmes. The ENZAFRUIT New Zealand Integrated Fruit Production Pipfruit Manual (Anon. 1998) suggests that IMC can be maintained with restricted use of dithiocarbamate (EDBC) fungicides, including metiram, ziram and thiram. However, the use of other non-disruptive fungicides is the preferred recommendation.

In Trial 1, an analysis comparing fungicide active ingredient with either granule (WG) or powder (WP) formulations of captan, thiram and ziram showed that active ingredient rather than fungicide formulation was the factor that affected predatory mite numbers.

Ziram, captan and thiram are the main fungicides used for the combined control of black spot and fungal rots, particularly bitter rot and ripe spot in mid- to latesummer. However the use of captan is already restricted for some markets and export varieties. In Trial 2, the fungicide tolylfluanid, compared favourably against ziram for compatibility with IMC when used in mid-summer. It did not suppress $T$. pyri populations whereas ziram suppressed predator levels in both trials. This suggests that the overuse of ziram at any time during the growing season is likely to result in ERM numbers increasing during mid-and late-summer. These results indicate that tolylfluanid is compatible with IMC and could be a practical alternative to ziram and thiram for mid- to late-summer fungicide use.

\section{ACKNOWLEDGEMENTS}

Funding from the Foundation for Research Science and Technology, Contract No. CO6616 supported this research. We are also grateful to Bayer New Zealand Ltd for their financial contribution for the second trial. Roger Wallis and Vanessa White provided technical assistance.

\section{REFERENCES}

Anon., 1998. New Zealand Integrated Fruit Production - Pipfruit Manual. Published by ENZAFRUIT New Zealand (International), Hastings.

Biobest 1998. Side effects of pesticides on beneficial organisms. Biobest Biological Systems. $12 \mathrm{pp}$.

Collyer, E., 1980. Integrated control of apple pests in New Zealand. 16. Progress with integrated control of the European red mite. N.Z. J. Zool. 7: 171-179.

Hassan, S.A., Albert, R., Bigler, F., Blaisinger, P., Bogenschutz, H., Boller, E., Brun, J., Chiverton, P., Edwards, P., Englert, W. D., Huang, P., Inglesfield, C., Naton, 
E., Oomen, P. A., Overmeer, W. P. J., Rieckmann, W., Samsoe-Peterson, L., Staubli, A., Tuset, J. J., Viggiani, G. and Vanwetswinkel, G., 1987. Results of the third joint pesticide testing programme by the IOBC/WPRS Working Group 'Pesticides and Beneficial Organisms'. Z. angew. Entomol. 103: 92-107.

Walker, J.T.S., Wearing, C.H., Shaw, P.W., Charles, J.G. and Hayes, A.J., 1989. Investigating the impact of protectant fungicides on integrated mite control. II. Results of three field experiments. Proc. 42 nd N.Z. Weed and Pest Control Conf.: $152-158$.

Wearing, C.H. and Ashley, E., 1982. A recommended spray programme for integrated mite control on apples. Orchardist of N.Z. 55: 27-29.

Wearing, C.H. and Proffit, C.A., 1982. Integrated control of apple pests in New Zealand. 18. Introduction and establishment of the organophosphate-resistant predatory mite Typhlodromus pyri in the Waikato. Proc. 35th N.Z. Weed and Pest Control Conf.: 22-26.

Wearing, C.H. and Wilton, W.J.W., 1984. Black spot fungicides and integrated mite control. Orchardist of N.Z. 57: 30-31. 